Kan, M. O. ve Duman, S. (2021). Üniversiteye giriş sınavlarında yer alan Türkçe testlerindeki paragraf sorularının çeşitli açılardan incelenmesi. Ana Dili Eğitimi Dergisi, 9(3), 1012-1021.

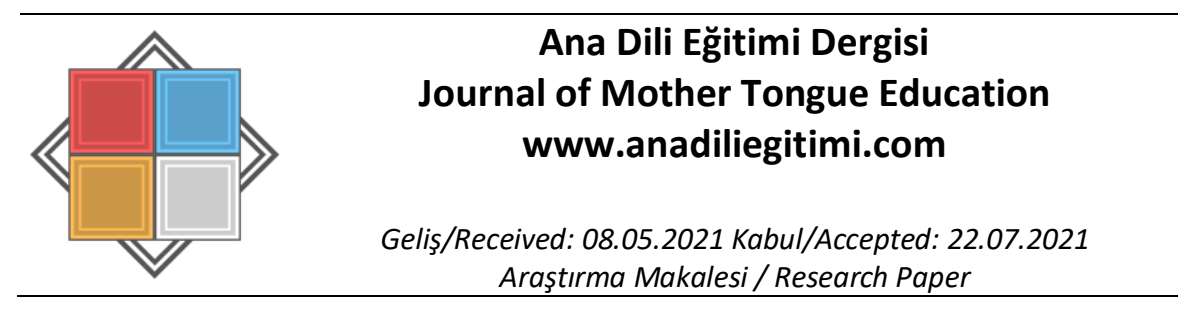

\title{
Üniversiteye Giriş Sınavlarında Yer Alan Türkçe Testlerindeki Paragraf Sorularının Çeşitli Açılardan İncelenmesi
}

\author{
Mustafa Onur KAN* \\ Seyran DUMAN**
}

\begin{abstract}
Öz
Bu çalışmanın amacı 2011-2020 yılları arasında yapılan üniversiteye giriş sınavlarında yer alan Türkçe testlerindeki paragraf sorularının sayısını, madde köklerini, paragrafı oluşturan sözcük sayısını ve söz konusu soruların Yenilenmiş Bloom Taksonomisi'ne göre hangi bilgi alanı ve bilişsel süreç boyutunda olduğunu belirlemektir. Nitel araştırma yaklaşımlarından temel nitel araştırma deseninde tasarlanan bu araştırmada verilerin toplanmasında doküman analizi kullanılmıştır. 20112020 yılları arasında üniversiteye giriş sınavlarının Türkçe testlerinde yer alan 240 paragraf sorusu incelenmiştir. Araştırmada ulaşılan temel sonuçlar şunlardır: Paragraf sorularının sayısı yıllara göre değişmekle beraber Türkçe testlerindeki soruların en az yüzde 50'sinin paragraf sorusu olduğu belirlenmiştir. 2018 ve sonrasına ait Türkçe testlerindeki paragraf sorularında paragraf başına düşen ortalama sözcük sayısının önceki yıllara göre artış gösterdiği bulgulanmıştır. Taksonominin bilişsel süreç boyutuna dair, incelenen paragraf sorularının büyük bölümünün anlama basamağında olduğu, çözümleme basamağındaki sorulara ise az da olsa yer verildiği, ayrıca söz konusu taksonominin bilgi alanı boyutuna dair de ele alınan paragraf sorularının tamamının kavramsal bilgi düzeyinde olduğu belirlenmiştir. Çalışmada ele alınan paragraf sorularında en çok görülen madde köklerinin "parçada anlatılan kişi ya da yapıta, parçadaki sözleri söyleyene ilişkin yorum ve çıkarımlar" ve "paragrafın ana düşüncesi" olduğu; en az görülenlerin ise "anlatım biçimleri" ve "paragrafın ana duygusu" olduğu tespit edilmiştir.
\end{abstract}

Anahtar Kelimeler: Üniversiteye giriş sınavları, paragraf soruları, Yenilenmiş Bloom Taksonomisi

\section{Examination of Paragraph Questions in Turkish Tests of University Entrance Exams from Various Aspects}

\begin{abstract}
The purpose of this study is to determine the number of paragraph questions, item stems, the number of words that constitute the paragraph, and which knowledge and cognitive process dimension of these questions according to the Revised Bloom's Taxonomy in Turkish tests of university entrance exams held between 2011-2020. In this study, which was designed in the basic qualitative research, document analysis was used to collect the data. 240 paragraph questions in Turkish tests of university entrance exams between 2011-2020 were investigated. The main results achieved in the study are as follows: Although the number of paragraph questions varies over the years, it has been determined that at least 50 percent of the questions in Turkish tests are paragraph questions. It was found that the average number of words per paragraph in paragraph questions of Turkish tests for 2018 and after has increased compared to previous years. With respect to the cognitive process dimension of the taxonomy, most of the paragraph questions examined on were in the understanding level, and the questions in the analyzing step were given
\end{abstract}

\footnotetext{
* Doç. Dr., Hatay Mustafa Kemal Üniversitesi, Eğitim Fakültesi, Temel Eğitim Bölümü, Hatay, mustafaonurkan@gmail.com, ORCID: orcid.org/ 0000-0001-8319-0791

${ }^{* *}$ Yüksek lisans öğrencisi, Hatay Mustafa Kemal Üniversitesi, Sosyal Bilimler Enstitüsü, Temel Eğitim Anabilim Dalı, Hatay, seyran_ege@hotmail.com, ORCID: orcid.org/0000-0001-5930-3362
} 
a few places. In addition, with respect to the knowledge dimension of the taxonomy it was determined that all of the paragraph questions were at the level of conceptual knowledge. The most common item stems in the paragraph questions examined in the study are "comments and inferences about the person or work described in the piece, the person who says the words in the piece" and "the main idea of the paragraph"; the least common ones were found to be "narration styles" and "main emotion of the paragraph".

Keywords: University entrance exams, paragraph questions, Revised Bloom Taxonomy

\section{Giriş}

Türkiye'de öğrenciler 1974'ten beri merkezî sınavlarla yükseköğretim kurumlarına yerleştirilmektedir. 19 Kasım 1974'te yükseköğretime giriş sınavlarının tek merkezden gerçekleştirilmesi için Üniversitelerarası Öğrenci Seçme ve Yerleştirme Merkezi kurulmuş ve 1981 yılına kadar üniversitelere öğrenci seçme ve yerleştirme işlemleri söz konusu merkez tarafından gerçekleştirilmiştir (ÖSYM, 2021). 1981'de Öğrenci Seçme ve Yerleştirme Merkezi, daha sonra 3 Mart 2011'de Ölçme Seçme ve Yerleştirme Merkezi olarak adlandırılııştır (ÖSYM, 2021). Bu merkezin gerçekleştirdiği yükseköğretime giriş sınavlarının adı ve oturum sayısı yıllar içinde değişiklik göstermektedir.

Yükseköğretim kurumlarına öğrenci seçmek amacıyla yapılan sınavlarda Türkçe testleri önemli bir yer tutmaktadır. Örneğin, altı puan türünün bulunduğu Yükseköğretime Geçiş Sınavı'nda (YGS), Türkçe testinin puan türlerine göre ağırlığı YGS-1 ve YGS-2 için yüzde 20, YGS-3 için yüzde 40, YGS-4 için yüzde 30, YGS-5 için yüzde 37 ve YGS-6 için yüzde 33'tür (ÖSYM, 2017). Benzer şekilde, Temel Yeterlilik Testi'nde (TYT) ise tüm adaylar için tek tip puan olmakla beraber Türkçe testinin ağırlığı yüzde 33'tür (YÖK, 2018). Buna göre, yapılan sınavlarda Türkçe testlerinin puan türlerine göre ağırlığının yıllara göre değişiklik göstermekle birlikte- oldukça önemli olduğu görülmektedir. Türkçe testlerinde de paragraf sorularının dikkate değer bir yer tuttuğu söylenebilir. Dursunoğlu (2002) da yükseköğretim kurumlarına öğrenci seçme sınavlarında, Türkçe sorularının çoğunluğunun paragraf sorularından oluştuğunu belirtmektedir. Sınavın adı veya puan türü değişse de Türkçe testlerinin -dolayısıyla bu testte yer alan paragraf sorularının- sınava katılan tüm adaylar için önemli olduğu anlaşılmaktadır.

YGS ve TYT'deki Türkçe testinin amacı, "Türkçeyi doğru kullanma, okuduğunu anlama ve yorumlama, kelime hazinesi, temel cümle bilgisi ve imla kurallarını kullanma becerilerini ölçmektir" (YÖK, 2018). Soruların bu becerileri hangi seviyede ölçtüğünü belirlemek amacıyla Bloom Taksonomisi en sık kullanılan yaklaşımdır (Yıldııım, 2020). Bloom Taksonomisi, soruların hangi bilişsel süreç ve bilgi boyutunda olduğunun anlaşılmasını sağlamaktadır.

2000 yılında yenilenen Bloom Taksonomisi'nin kategorileri, hedeflerle uyum sağlayabilmesi için isim ve eylem olarak iki boyutlu düzenlenmiştir (Arı, 2013). İsim hâli, hedeflerin bilgi boyutunu, eylem hâli ise hedeflerin bilişsel boyutunu temsil etmektedir. Bilgi boyutu olgusal bilgi, kavramsal bilgi, işlemsel bilgi ve üst bilişsel bilgi; bilişsel süreç boyutu ise hatırlama, anlama, uygulama, çözümleme, değerlendirme ve yaratma olarak ayrılmaktadır (Çintaş Yıldız, 2015). Bilgi boyutundaki olgusal bilgi bir konu hakkında bilinmesi gereken en temel bilgi olarak tanımlanabilir. Kavramsal bilgi sınıflamalar, kategoriler, ilkeler, prensipler, genellemeler, kuram, yapı ve modellere ilişkin bilgileri kapsar (Bümen, 2006). Kavramsal bilgi, olgusal bilgiye göre üst düzey düşünme becerisi gerektiren bilgidir. İşlemsel bilgi çözüm için nasıl bir yöntem uygulanacağı ile ilgili bilgidir. Üst bilişsel bilgi de kişinin kendi bilişinin farkında olması ile ilgilidir (Bümen, 2006). Yenilenmiş Bloom Taksonomisi'nin bilişsel süreç boyutundaki hatırlama basamağı "ilgili bilgiyi uzun süreli bellekten geri getirme"; anlama basamağı "öğretimsel mesajdan sözel, yazılı ya da grafiksel bir iletişim olarak anlam oluşturma"; uygulama basamağı "verilen bir durumda işlemi uygulama ya da kullanma"; çözümleme basamağı "materyali bileşenlerine ayırma ve parçaların birbiriyle / bütünle nasıl bir ilişki içinde olduğunu tespit etme"; değerlendirme basamağı "ölçütlere ve standartlara dayalı yargıya varma" ve yaratma basamağı "öğeleri tutarlı ya da işlevsel bir yapıda bir araya getirme, öğeleri yeni bir örüntü ya da yapı içerisinde yeniden düzenleme" olarak açıklanmaktadır (Anderson vd. 2001'den Akt. Bümen, 2006).

Illgili alanyazında Vural (2020) liselere giriş sınavında çıkan Türkçe sorularını; Çintaş Yıldız (2015) ortaokul Türkçe sınav sorularını; Erdoğan (2017) ilkokul dördüncü sını öğretmen ve öğrencilerinin 
Türkçe dersinde sordukları soruları Yenilenmiş Bloom Taksonomisi açısından değerlendirmiştir. Dursunoğlu (2002) ise öğrenci seçme sınavlarındaki Türkçe sorularını ortaöğretimdeki Türk Dili ve Edebiyatı öğretim programları ile karşılaştırmıştır. Alanyazındaki çalışmalara bakıldığında üniversiteye giriş sınavlarındaki Türkçe soruları ile ilgili çalışmalarının oldukça sınırlı sayıda olduğu görülmektedir. Ayrıca, merkezî sınavların Türkçe testlerinde ağılıklı olarak yer alan paragraf sorularına odaklanılan yeterli çalışma bulunmamaktadır.

Bu araştırmanın genel amacı 2011-2020 yılları arasında üniversiteye giriş sınavlarında yer alan Türkçe testlerindeki paragraf sorularını çeşitli açılardan incelemektir. Bu genel amaca bağlı olarak araştırmanın alt amaçları şunlardır:

2011-2020 yılları arasında yapılan üniversiteye giriş sınavlarında yer alan Türkçe testlerindeki;

1. Paragraf sorularının sayısını ve söz konusu paragrafların sözcük sayısını belirlemek,

2. Paragraf sorularının Yenilenmiş Bloom Taksonomisi'ne göre hangi bilgi alanı ve bilişsel süreç boyutunda olduğunu belirlemek,

3. Paragraf sorularının madde köklerini belirlemektir.

\section{Araştırmanın Modeli}

\section{Yöntem}

Bu çalışma, nitel araştırma yaklaşımlarından temel nitel araştırma deseninde (Merriam, 2013) tasarlanmıştır. Algı ve olayların gerçekçi ve bütüncül bir şekilde ortaya konmasına yönelik bir araştırma türü olan nitel araştırma yönteminde görüşme, gözlem ve doküman incelemesi en yaygın kullanılan bilgi toplama yöntemidir (Yıldırım, 1999).

\section{Verilerin Toplanması ve Analizi}

Verilerin toplanmasında doküman analizi kullanılan bu araştırmada, 2011-2020 yılları arasında üniversiteye giriş sınavlarında yer alan Türkçe testlerindeki paragraf sorularının incelenmesi amaçlandığı için Ölçme, Seçme ve Yerleştirme Merkezi Başkanlığına ait internet adresinden ilgili yılların sorularına ulaşılmıştır. 2011-2020 yılları arasında üniversiteye giriş sınavlarının Türkçe testlerinde sınava katılanlara 40'ar soru yöneltildiğinden söz konusu yıllara ait toplam 400 Türkçe sorusu bulunmaktadır. Bu soruların 240'ının paragraf sorusu olduğu belirlenmiş ve soruların tamamı araştırmanın amaç ve alt amaçları açısından incelenmiştir.

Araştırmanın "2011-2020 yılları arasında yapılan üniversiteye giriş sınavlarında yer alan Türkçe testlerindeki paragraf sorularının sayısını ve söz konusu paragrafların sözcük sayısını belirlemek" alt amacına dair, paragraf soruları belirlendikten sonra her bir yıldaki paragraf sorusu sıklığı, paragraf sorularının toplam Türkçe sorusu içindeki yüzdesi, paragraf sorularındaki toplam sözcük sayısı ve paragraf başına düşen ortalama sözcük sayısı betimlenmiştir.

"2011-2020 yılları arasında yapılan üniversiteye giriş sınavlarında yer alan Türkçe testlerindeki paragraf sorularını Yenilenmiş Bloom Taksonomisi'ne göre hangi bilgi alanı ve bilişsel süreç boyutunda olduğunu belirlemek" alt amacına dair, paragraf soruları Yenilenmiş Bloom Taksomisi'nin boyutları açısından incelendikten sonra ilgili yıllara göre sıklık ve yüzdeler sunulmuştur.

Araştırmanın "2011-2020 yılları arasında yapılan üniversiteye giriş sınavlarında yer alan Türkçe testlerindeki paragraf sorularının madde köklerini belirlemek" alt amacına dair ise Dursunoğlu'nun (2002) paragraf sorularının madde köklerine dair sınıflandırması temel alınmıştır. Söz konusu sınıflandırmada karşıı̆ı̆ bulunamayan paragraf sorularına ilişkin madde kökleri de sınıflandırmaya eklenerek yıllara göre paragraf sorularının madde kökleri sıklıkları ile sunulmuştur.

Araştırmada elde edilen verilerin güvenilirliğini sağlamak amacıyla biri Türkçe eğitimi alanında, ikisi program geliştirme alanında uzman olmak üzere üç öğretim üyesiyle değerlendirme toplantısı yapılmıştır. Elde edilen veriler söz konusu uzmanlara sunulmuş ve araştırmada ulaşılan verilere dair karşılıklı görüş birliğine varılmıştır.

\section{Araştırma ve Yayın Etiği}

Bu çalışmada "Yükseköğretim Kurumları Bilimsel Araştırma ve Yayın Etiği Yönergesi" kapsamında uyulması belirtilen tüm kurallara uyulmuştur. Yönergenin ikinci bölümü olan "Bilimsel 
Araştırma ve Yayın Etiğine Aykırı Eylemler" başlığı altında belirtilen eylemlerden hiçbiri gerçekleştirilmemiştir. Bu çalışma; anket, mülakat, gözlem, deney ve görüşme teknikleri gibi katılımcılardan veri toplanan bir çalışma olmayıp doküman incelemesine (üniversiteye giriş sınavları) dayalı nitel bir yaklaşımla gerçekleştirilmiş olup etik kurul izni gerektirmemektedir.

\section{Bulgular}

Bu bölümde, araştırmanın alt amaçlarına ait bulgulara yer verilmiştir.

\section{Paragraf Sorularının Sayısı ve Söz Konusu Paragraflardaki Sözcük Sayısına iliş̧kin Bulgular}

2011-2020 yılları arasında üniversite giriş sınavlarında yer alan Türkçe testlerindeki paragraf soru sayısının ve söz konusu paragraflardaki sözcük sayısının yıllara göre dağılımı Tablo 1'de sunulmaktadır.

Tablo 1.

Paragraf Sorularının Sayısı ve Paragraflardaki Sözcük Sayısı

\begin{tabular}{ccccc}
\hline $\begin{array}{c}\text { Sınav } \\
\text { Yılı }\end{array}$ & $\begin{array}{c}\text { Paragraf } \\
\text { Soru Sayısı }\end{array}$ & $\begin{array}{c}\text { Toplam Türkçe Sorusu } \\
\text { içindeki Yüzdesi }\end{array}$ & $\begin{array}{c}\text { Paragraf Sorularındaki } \\
\text { Toplam Sözcük Sayısı }\end{array}$ & $\begin{array}{c}\text { Paragraf Başına Düşen } \\
\text { Ortalama Sözcük Sayısı }\end{array}$ \\
\hline 2011 & 24 & 60 & 1667 & 69,45 \\
2012 & 25 & 62,5 & 2000 & 80 \\
2013 & 21 & 52,5 & 1546 & 73,61 \\
2014 & 25 & 62,5 & 1848 & 73,92 \\
2015 & 27 & 67,5 & 1919 & 71,07 \\
2016 & 26 & 65 & 1555 & 59,80 \\
2017 & 21 & 52,5 & 1413 & 67,28 \\
2018 & 22 & 55 & 1768 & 80,36 \\
2019 & 22 & 55 & 1819 & 82,68 \\
2020 & 27 & 67,5 & 2164 & 80,14 \\
\hline
\end{tabular}

Tablo 1'de, 2011-2020 sınavlarında yer alan Türkçe testlerindeki paragraf soru sayılarının yıllara göre farklılık gösterdiği görülmektedir. İncelenen sınavlar arasında en çok paragraf sorusunun 2015 ve 2020 yıllarında yer aldığı belirlenmiştir. Ayrıca, 2011-2020 yılları arasında gerçekleştirilen üniversite giriş sınavlarının Türkçe testlerinde paragraf sorularının oranının hiçbir yılda \%50'nin altında olmadığı görülmektedir.

Tablo 1'de görüldüğü gibi, incelenen yıllar arasında paragraf sorularındaki toplam sözcük sayısının en yüksek olduğu yıl 2020, en düşük olduğu yıl ise 2017'dir. Bununla birlikte, paragraf başına düşen ortalama sözcük sayısı incelendiğinde en yüksek ortalamanın 2019 yılına, en düşük ortalamanın ise 2016 yılına ait olduğu bulgulanmıştır. Ayrıca, 2011, 2016 ve 2017 yılları dışında paragraf başına düşen ortalama sözcük sayısının 70'in üzerinde olduğu belirlenmiştir.

\section{Paragraf Sorularının Yenilenmiş Bloom Taksonomisi'nin Bilgi Alanı ve Bilişsel Süreç Boyutuna ilişkin Bulgular}

2011-2020 yılları arasında yapılan üniversiteye giriş sınavlarında yer alan Türkçe testlerindeki paragraf soruları Yenilenmiş Bloom Taksonomisi'nin bilişsel süreç boyutuna göre incelendiğinde hatırlama, uygulama, değerlendirme ve yaratma boyutlarında paragraf sorusu bulunmadığı belirlenmiştir. Incelenen paragraf sorularının tamamının anlama veya çözümleme boyutunda olduğu tespit edilmiştir. Söz konusu sorulara ilişkin dağılım Tablo 2'de yer almaktadır. 
Üniversiteye Giriş Sınavlarında Yer Alan Türkçe Testlerindeki Paragraf Sorularının Çeşitli Açılardan Incelenmesi

Tablo 2.

Paragraf Sorularının Yenilenmiş Bloom Taksonomisi'nin Bilişsel Süreç Boyutuna Göre Dağııımı

\begin{tabular}{|c|c|c|c|c|}
\hline \multirow[t]{3}{*}{ Sınav Yılı } & \multicolumn{4}{|c|}{ Bilişsel Süreç Boyutu } \\
\hline & \multicolumn{2}{|r|}{ Anlama } & \multicolumn{2}{|r|}{ Çözümleme } \\
\hline & $f$ & Paragraf Soruları İçindeki Yüzdesi & $f$ & Paragraf Soruları İçindeki Yüzdesi \\
\hline 2011 & 17 & 71 & 7 & 29 \\
\hline 2012 & 22 & 88 & 3 & 12 \\
\hline 2013 & 18 & 86 & 3 & 14 \\
\hline 2014 & 19 & 76 & 6 & 24 \\
\hline 2015 & 19 & 70 & 8 & 30 \\
\hline 2016 & 19 & 73 & 7 & 27 \\
\hline 2017 & 14 & 67 & 7 & 33 \\
\hline 2018 & 18 & 82 & 4 & 18 \\
\hline 2019 & 18 & 82 & 4 & 18 \\
\hline 2020 & 22 & 81 & 5 & 19 \\
\hline
\end{tabular}

Tablo 2'de, 2011-2020 yılları arasında yapılan üniversiteye giriş sınavlarında yer alan Türkçe testlerinin tamamında paragraf sorularının çoğunun anlama düzeyinde olduğu görülmektedir. Ayrıca yüzdesi yıllara göre değişmekle birlikte- incelenen paragraf soruları arasında çözümleme boyutunda soruların da yer aldığı belirlenmiştir. Anlama boyutuna dair soruların en çok 2012 ve 2020'de yapılan; çözümleme boyutuna dair ise en çok 2015 yılında yapılan üniversiteye giriş sınavlarının Türkçe testlerindeki paragraf sorularında yer aldığı bulgulanmıştır.

Üniversite giriş sınavlarında yer alan Türkçe testlerindeki paragraf soruları Yenilenmiş Bloom Taksonomisi'nin bilgi alanı boyutuna göre incelendiğinde 2011-2020 yılları arasındaki paragraf sorularının tamamının kavramsal bilgi boyutundu olduğu belirlenmiştir. Olgusal bilgi, işlemsel bilgi ve üst bilişsel bilgi boyutlarında ise anılan yıllarda Türkçe testlerinde paragraf sorusu bulunmadığı tespit edilmiştir.

\section{Paragraf Sorularının Madde Kökü Dağılımına iliş̧kin Bulgular}

2011-2020 yılları arasında yapılan üniversite giriş sınavlarında yer Türkçe testlerindeki paragraf sorularının madde kökü dağılımına ilişkin bulgular Tablo 3'te sunulmaktadır.

Tablo 3.

Paragraf Sorularının Madde Kökü Dağılımı

Madde Kökü $\quad$ Sınav Yılı ve Soru Sayısı

\begin{tabular}{|c|c|c|c|c|c|c|c|c|c|c|c|}
\hline & 공 & 芩 & $\stackrel{n}{\stackrel{n}{\sim}}$ & 㭊 & 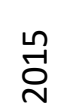 & $\stackrel{0}{\stackrel{1}{0}}$ & خे & $\stackrel{\infty}{\stackrel{\infty}{\sim}}$ & 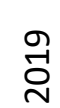 & 유 & $\frac{\frac{\varepsilon}{\pi}}{\frac{\pi}{0}} \frac{}{\circ}$ \\
\hline $\begin{array}{l}\text { Parçada anlatılan kişi ya da yapıta, } \\
\text { parçadaki sözleri söyleyene ilişkin yorum } \\
\text { ve çıkarımlar }\end{array}$ & 3 & 10 & 8 & 4 & 4 & 2 & 2 & 8 & 7 & 10 & 58 \\
\hline Paragrafın ana düşüncesi & 2 & 2 & 3 & 4 & 2 & 3 & 2 & 8 & 4 & 5 & 35 \\
\hline Paragraftan çıkarılamayacak yargı & 3 & 4 & 1 & 1 & 2 & 5 & 3 & 0 & 3 & 2 & 24 \\
\hline $\begin{array}{l}\text { Paragraftaki bir sözü, paragrafa göre } \\
\text { değerlendirmek }\end{array}$ & 4 & 2 & 1 & 2 & 4 & 4 & 1 & 0 & 1 & 2 & 21 \\
\hline Düşünceyi geliştirme yolları & 2 & 2 & 1 & 3 & 2 & 2 & 2 & 1 & 1 & 1 & 17 \\
\hline Sonuç cümlesi & 2 & 1 & 2 & 3 & 3 & 1 & 1 & 1 & 0 & 1 & 15 \\
\hline
\end{tabular}




\begin{tabular}{|c|c|c|c|c|c|c|c|c|c|c|c|}
\hline $\begin{array}{l}\text { Paragrafta değinilmeyen yargı ya da } \\
\text { durum }\end{array}$ & 1 & 0 & 1 & 3 & 2 & 2 & 3 & 1 & 1 & 0 & 14 \\
\hline $\begin{array}{l}\text { Cümleleri anlamlı bir bütün oluşturmak } \\
\text { için sıralamak veya verilen bir cümleyi } \\
\text { uygun yere getirmek }\end{array}$ & 1 & 0 & 0 & 1 & 3 & 3 & 2 & 0 & 0 & 1 & 11 \\
\hline Bir parçayı iki paragrafa bölme & 1 & 0 & 1 & 1 & 1 & 1 & 2 & 1 & 1 & 1 & 10 \\
\hline Paragrafın düşünce akışını bozan cümle & 1 & 1 & 0 & 1 & 1 & 1 & 1 & 1 & 1 & 1 & 9 \\
\hline $\begin{array}{l}\text { Paragrafta boş bırakılan yere gelebilecek } \\
\text { ifade }\end{array}$ & 2 & 0 & 0 & 0 & 0 & 1 & 1 & 1 & 1 & 1 & 7 \\
\hline Paragrafın yanıt oluşturduğu soru & 2 & 1 & 0 & 0 & 2 & 0 & 0 & 0 & 0 & 1 & 6 \\
\hline Anlatım tekniği & 0 & 1 & 2 & 1 & 0 & 0 & 0 & 0 & 0 & 0 & 4 \\
\hline Paragrafın konusu & 0 & 0 & 0 & 1 & 0 & 0 & 0 & 0 & 1 & 1 & 3 \\
\hline Giriş cümlesi & 0 & 1 & 0 & 0 & 0 & 0 & 0 & 0 & 1 & 0 & 2 \\
\hline Parçadan çıkarılabilecek en kapsamlı yargı & 0 & 0 & 0 & 0 & 1 & 1 & 0 & 0 & 0 & 0 & 2 \\
\hline Anlatım biçimleri & 0 & 0 & 1 & 0 & 0 & 0 & 0 & 0 & 0 & 0 & 1 \\
\hline Paragrafın ana duygusu & 0 & 0 & 0 & 0 & 0 & 0 & 1 & 0 & 0 & 0 & 1 \\
\hline
\end{tabular}

Tablo 3'e göre, 2011-2020 yılları arasında yapılan üniversiteye giriş sınavlarında yer alan Türkçe testlerindeki paragraf sorularında sırasıyla en çok "parçada anlatılan kişi ya da yapıta, parçadaki sözleri söyleyene ilişkin yorum ve çıkarımlar", "paragrafın ana düşüncesi" ve "paragraftan çıkarılamayacak yargı" madde kökü olarak görülmektedir. Buna karşın söz konusu yıllarda paragraf sorularında en az "paragrafın ana duygusu", "anlatım biçimleri", "giriş cümlesi" ve "parçadan çıkarılabilecek en kapsamlı yargı" madde kökü olarak yer almaktadır. Ayrıca, "parçada anlatılan kişi ya da yapıta, parçadaki sözleri söyleyene ilişkin yorum ve çıkarımlar", "paragrafın ana düşüncesi" ve "düşünceyi geliştirme yolları" da incelenen yılların tamamında paragraf sorularında belirlenen madde kökleridir.

\section{Tartışma ve Sonuç}

Türkiye'de yükseköğretime öğrenci seçme amacı taşıyan merkezî sınavların Türkçe testi, sınava katılan öğrenciler için -katsayısı ve soru sayısı göz önünde bulundurulduğunda- önemli bir yere sahiptir. 2011-2020 yılları arasında yapılan üniversiteye giriş sınavlarında yer alan Türkçe testlerindeki paragraf sorularının çeşitli açılardan incelendiği bu araştırmada, yıllara göre paragraf soru sayısının aynı olmamakla beraber Türkçe sorularının en az yüzde 50'sinin paragraf sorusu olduğu belirlenmiştir. Paragrafı okuma hızı ve okuduğunu anlama gücünün öğrencinin alacağı puanı etkilediği (Çetinkaya, 2009) düşünüldüğünde yükseköğretim için öğrenci seçmeyi amaçlayan bu sınavlarda paragraf soru sayısının diğer sorulara göre daha çok olması öngörülebilir bir durumdur.

Eğitim hedeflerini sınıflandırmanın amaçlarından biri sınama durumlarını standartlaştırmaktır (Yurdabakan, 2012). En çok kullanılan sınıflandırma ise Yenilenmiş Bloom Taksonomisi'dir. İncelenen Türkçe testlerindeki paragraf soruları Yenilenmiş Bloom Taksonomisi'nin bilişsel süreç boyutu açısından değerlendirildiğinde soruların büyük bölümünün anlama basamağında olduğu, çözümleme basamağındaki sorulara ise az da olsa yer verildiği görülmektedir. Ancak hatırlama, uygulama, değerlendirme ve yaratma basamağında soru bulunmamaktadır. Bu durum üniversiteye giriş sınavlarının Türkçe testlerinde yer alan paragraf sorularının öğrencilerin üst düzey düşünme becerilerini ölçmediğini göstermektedir. Liselere giriş sınavlarındaki Türkçe sorularını inceleyen Vural'ın (2020) araştırmasında da soruların bilişsel süreç basamaklarından anlama basamağında yoğunlaştığı; hatırlama, değerlendirme ve yaratma basamağına ait sorulara yer verilmediği sonucuna ulaşıımıştır. Alanyazında farklı alanlardaki soruları inceleyen çalışmalarda da (Örn. TEOG íngilizce sınavına dair: Demirci ve Gökdeniz, 2020; TEOG matematik sorularına dair: Yakalı, 2016) soruların üst düzey düşünme becerilerini ölçmediği ortaya konmuştur. Bununla birlikte, ÖSS'de sorulan Türkçe sorularını taksonomik açıdan değerlendiren Çetinkaya (2009), anlama dayalı soruların daha çok kavrama ve analiz düzeyinde olduğu sonucuna ulaşmasına karşın analiz basamağında bulunan soru sayısının kavrama basamağında bulunan soru sayısından daha fazla olduğu sonucuna varmıştır. Bu farklııık, mevcut çalışmada yalnızca paragraf sorularının incelenmesi ile açıklanabilir. 
Üniversite giriş sınavlarının Türkçe testindeki paragraf soruları Yenilenmiş Bloom Taksonomisi'nin hedef içeriğini gösteren bilgi boyutu açısından incelendiğinde soruların tamamının kavramsal bilgi düzeyinde olduğu tespit edilmiştir. Vural (2020) da araştırmasında liselere giriş sınavlarındaki Türkçe sorularının kavramsal bilgi düzeyinde yoğunlaştığı, bu sınavlarda işlemsel bilgi düzeyindeki sorulara az da olsa yer verildiği ancak olgusal bilgi ve üst bilişsel bilgi düzeyinde soru olmadığı sonucuna ulaşmıştır. Olgusal bilgi düzeyi bilişsel süreç basamağı olan hatırlama ile; kavramsal bilgi düzeyi anlama, değerlendirme ve yaratma basamağı ile; işlemsel bilgi düzeyi uygulama basamağı ile ilişkilendirilebilir (Krathwohl, 2002; Anderson, 2005, akt. Yurdabakan, 2012). Dolayısıyla paragraf soruları, okuduğunu anlayabilme/yorumlayabilme becerisi gerektirdiği için olgusal bilgi düzeyinde soru olmaması anlaşılabilir bir durumdur. Bununla birlikte üst bilişsel bilgi, kişinin kendi bilişi hakkındaki farkındalık düzeyi (Yurdabakan, 2012) olduğundan üst bilişsel bilginin çoktan seçmeli sorular ile ölçülemeyeceği söylenebilir.

Üniversiteye giriş sınavlarında yer alan Türkçe testlerindeki paragraf soruları madde kökleri açısından incelendiğinde en çok görülen madde köklerinin "parçada anlatılan kişi ya da yapıta, parçadaki sözleri söyleyene ilişkin yorum ve çıkarımlar" ve "paragrafın ana düşüncesi" olduğu; en az görülenlerin ise "anlatım biçimleri" ve "paragrafın ana duygusu" olduğu belirlenmiştir. Calp ve Alpkaya (2021), LGS Türkçe sorularının Türkçe Dersi Öğretim Programı kazanımlarına uygunluğu üzerine yaptıkları çalışmada soruların çoğunun bir metni yorumlama, çıkarımlarda bulunma, metnin ana fikrini belirlemeye yönelik olduğunu tespit etmişlerdir. Dursunoğlu (2002), öğrenci seçme sınavlarındaki Türkçe sorularını orta öğretimdeki Türk Dili ve Edebiyatı programları ile karşılaştırdığı çalışmasında en fazla sorunun paragrafın ana düşüncesi ile ilgili olduğunu ortaya koymuştur. Dolayısıyla alanyazındaki çalışmalarla mevcut araştırma sonuçlarının benzerlik gösterdiği söylenebilir.

Yükseköğretime giriş sınavları belirli bir sürede gerçekleştirildiğinden paragraf uzunluğu, dolayısıyla sözcük sayısı sınava katılanlar açısından oldukça önemlidir. Paragraftaki sözcük sayısı arttıkça öğrencilerin sorulara ayırdığı sürenin de artması beklenir. Bu çalışmada Türkçe testlerindeki paragraf sorularının toplam sözcük sayısı ile paragraf başına düşen ortalama sözcük sayısının yıllara göre farklılık gösterdiği belirlenmiştir. 2018 ve sonraki yıllarda paragraf başına düşen ortalama sözcük sayısı diğer yıllara göre artış göstermiştir. Dolayısıyla sınava katılanların yalnızca okuduğunu anlamasının yeterli olmadığı, okuduğunu hızlı bir şekilde anlama becerisine sahip olması gerektiği söylenebilir.

Araştırmada ulaşılan sonuçlardan hareketle aşağıda yer alan öneriler geliştirilebilir:

Üniversiteye giriş sınavlarının Türkçe testlerindeki paragraf sorularında Yenilenmiş Bloom Taksonomisi'nin üst düzey düşünmeye dair boyutlarına yönelik de paragraf sorularına yer verilmesi gerektiği düşünülmektedir. Bu bağlamda üniversiteye giriş sınavlarının Türkçe testlerinde çoktan seçmeli sorularla birlikte açık uçlu sorular da kullanılabilir.

Paragrafları oluşturan sözcük sayılarına ilişkin bulgular göz önünde bulundurulduğunda okuduğunu hızlı bir şekilde anlama becerisine yönelik çalışmalar yapılabilir.

\section{Araştırma ve Yayın Etiği}

Bu çalışmada "Yükseköğretim Kurumları Bilimsel Araştırma ve Yayın Etiği Yönergesi" kapsamında uyulması belirtilen tüm kurallara uyulmuştur. Yönergenin ikinci bölümü olan "Bilimsel Araştırma ve Yayın Etiğine Aykırı Eylemler" başlığı altında belirtilen eylemlerden hiçbiri gerçekleştirilmemiştir.

\section{Yazarların Katkı Oranı}

Araştırmacılar çalışmaya eşit oranda katkı yapmışlardır.

\section{Çıkar Çatışması}

Çalışma kapsamında herhangi bir kişisel ve finansal çıkar çatışması bulunmamaktadır. 


\section{Kaynaklar}

Arı, A. (2013). Bilişsel alan sınıflamasında yenilenmiş Bloom, Solo, Fink, Dettmer taksonomileri ve uluslararası alanda tanınma durumları. Uşak Üniversitesi Sosyal Bilimler Dergisi, $\quad$ 6(2), 259290.

Bümen, N. (2006). Program geliştirmede bir dönüm noktası: Yenilenmiş Bloom Taksonomisi. Eğitim ve Bilim, 31(142), 3-14.

Calp, M. ve Alpkaya, C. (2021). LGS Türkçe sorularının Türkçe dersi öğretim programı kazanımlarına uygunluğu üzerine bir çalışma. Ana Dili Eğitimi Dergisi, 9(2), 632-654.

Çetinkaya, S. (2009). ÖSS'de sorulan Türkçe sorularının taksonomik açıdan değerlendirilmesi (Yayımlanmamış yüksek lisans tezi). Gazi Üniversitesi Eğitim Bilimleri Enstitüsü, Ankara.

Çintaş Yıldız, D. (2015). Türkçe dersi sınav sorularının yeniden yapılandırılan Bloom taksonomisine gör analizi. Gaziantep University Journal of Social Sciences, 14(2), 479-497.

Demirci, C. ve Gökdeniz, M. (2020). TEOG sınavı İngilizce sorularının İngilizce öğretim programına uygunluğu ve Yenilenmiş Bloom Taksonomisine göre sınıflandırılması. Education Sciences, 15(1) 1-10.

Dursunoğu, H. (2002). Öğrenci seçme sınavlarındaki Türkçe sorularının orta öğretimdeki Türk Dili ve Edebiyatı öğretim programları ile karşılaştırılması (Yayımlanmamış doktora tezi). Atatürk Üniversitesi Sosyal Bilimler Enstitüsü, Erzurum.

Erdoğan, T. (2017). Illkokul dördüncü sınıf öğrencilerinin ve öğretmenlerinin Türkçe dersine ilişkin sordukları soruların Yenilenmiş Bloom Taksonomisi açısından görünümü. Eğitim ve Bilim, 42(192), 173-191.

Merriam, S. B. (2013). Nitel araştırma: Desen ve uygulama için bir rehber. Ankara: Nobel Yayınları.

ÖSYM, (2017). Öğrenci Seçme ve Yerleştirme Sistemi (ÖSYS) kılavuzu. Erişim adresi: https://dokuman.osym.gov.tr/pdfdokuman/2017/OSYS/KILAVUZ18042017.pdf

ÖSYM, (2021). Ölçme, Seçme ve Yerleştirme Başkanlığı hakkında. Erişim adresi: https://www.osym.gov.tr/TR,8789/hakkinda.html

Vural, C. (2020). Son 10 yılda yapılan liselere giriş sınavlarında (SBS, TEOG ve LGS) yer alan Türkçe dersi sorularının Yenilenmiş Bloom Taksonomisi açısından değerlendirilmesi (Yayımlanmamış yüksek lisans tezi). Gaziantep Üniversitesi Eğitim Bilimleri Enstitüsü, Gaziantep.

Yakalı, D. (2016). TEOG sınavlarındaki matematik sorularının yenilenmiş Bloom taksonomisi ve öğretim programına göre değerlendirilmesi (Yayımlanmamış yüksek lisans tezi). Adnan Menderes Üniversitesi Sosyal Bilimler Enstitüsü, Aydın.

Yıldırım, A. (1999). Nitel araştırma yöntemlerinin temel özellikleri ve eğitim araştırmalarındaki yeri ve önemi. Eğitim ve Bilim, 23(112).

Yıldırım, T. (2020). Kimya öğretmenlerinin yazılı sınav sorularının Yenilenmiş Bloom Taksonomisine göre analizi ve ÖSYM soruları ile karşılaştırılması. Pamukkale Üniversitesi Eğitim Fakültesi Dergisi, 50, 449-467.

Yurdabakan, í. (2012). Bloom'un revize edilen taksonomisinin eğitimde ölçme ve değerlendirmeye etkileri. Gaziantep Üniversitesi Sosyal Bilimler Dergisi, 11(2), 327-348.

YÖK. (2018). Yükseköğretim kurumları sınavı ile ilgili sıkça sorulan sorular ve cevapları. Erişim adresi: https://www.yok.gov.tr/Documents/AnaSayfa/yuksekogretim_kurumlari_sinavi_sss_ve_cev plari_puan_turleri_ile.pdf

\section{Introduction}

\section{Extended Abstract}

Turkish tests have an important place in the exams which aim to select students for higher education institutions. For example, in the Transition to Higher Education Exam (YGS) where there are six types of scores, the weight of the Turkish test according to the score types is 20 percent for YGS-1 and YGS-2, 40 percent for YGS-3, 30 percent for YGS-4, 37 percent for YGS-5 and 33 percent for YGS-6 (ÖSYM, 2017). Similarly, in the Basic Proficiency Test (TYT), although there is only one type of score for all candidates, the weight of the Turkish test is 33 percent (YÖK, 2018). Accordingly, it is seen that the weight of Turkish tests according to the types of points in the exams -although it varies according to 
years- is quite important. It can be said that paragraph questions have an important place in Turkish tests. Dursunoğlu (2002) also states that in the student selection exams for higher education institutions, most of the Turkish questions consist of paragraph questions. Although the name of the exam or the type of score changes, it is understood that the Turkish tests -therefore the paragraph questions in this test- are important for all candidates participating in the exam.

The purpose of this study is to determine the number of paragraph questions, item stems, the number of words that constitute the paragraph, and which knowledge and cognitive process dimension of these questions according to the Revised Bloom's Taxonomy in Turkish tests of university entrance exams between 2011-2020.

\section{Method}

This study was designed in the basic qualitative research design (Merriam, 2013), one of the qualitative research approaches. In qualitative research method, which is a type of research aimed at revealing perceptions and events in a realistic and holistic way, interview, observation and document analysis are the most commonly used information gathering methods (Yıldırım, 1999).

Document analysis was used in the collection of data. Since the aim of the study was to examine the paragraph questions in the Turkish tests of the university entrance exams between 2011 and 2020, the questions of the relevant years were obtained from the website of The Measuring, Selection and Placement Center (ÖSYM). Since 40 questions were asked to those who took the exam in the Turkish tests of the university entrance exams between 2011 and 2020, there are a total of 400 Turkish questions belonging to the aforesaid years. It was revealed that 240 of these questions were paragraph questions and all of these questions were examined in terms of the purpose and subpurposes of the research.

In order to ensure the dependability of the data obtained in the research, an evaluation meeting was held with three faculty members, one of whom was expert in the field of Turkish education and two of them were experts in the field of curriculum development. The data obtained were presented to the aforesaid experts and a mutual consensus was reached on the data obtained in the study.

\section{Result and Discussion}

When considering its coefficient and number of questions, the Turkish test of the central exams aiming to select students for higher education in Turkey has an important place for the students participating the exam. In this study, in which the paragraph questions of Turkish tests in the university entrance exams between 2011-2020 were examined from various aspects, it was determined that at least 50 percent of the Turkish questions were paragraph questions, although the number of paragraph questions by years was not the same. Considering that the speed of reading the paragraph and the reading comprehension power affect the score the student will get (Çetinkaya, 2009), it is predictable that the number of paragraph questions is higher in these exams, which aim to select students for higher education, compared to other questions.

With respect to the cognitive process dimension of the taxonomy, most of the paragraph questions examined on were in the understanding level, and the questions in the analyzing step were given a few places. However, there are no questions in the steps of remembering, applying, evaluating and creating. This situation shows that the paragraph questions in the Turkish tests of the university entrance exams do not measure the higher level thinking skills of the students.

When the paragraph questions in the Turkish test of the university entrance exams were examined in terms of the knowledge dimension showing the target content of the Revised Bloom Taxonomy, it was found that all of the questions were at the level of conceptual knowledge. Since paragraph questions require reading comprehension / interpreting skills, it is understandable that there are no questions at the level of factual knowledge. However, since metacognitive knowledge is the level of awareness about one's own cognition (Yurdabakan, 2012) it can be said that metacognitive knowledge cannot be measured with multiple choice questions. 
The most common item stems in the paragraph questions examined in the study are "comments and inferences about the person or work described in the piece, the person who says the words in the piece" and "the main idea of the paragraph"; the least common ones were found to be "narration styles" and "main emotion of the paragraph". Calp and Alpkaya (2021), in their study on the appropriateness of the LGS Turkish questions to the Turkish course curriculum outcomes, found that most of the questions were interpreting a text, making inferences, and determining the main idea of the text. Dursunoğlu (2002), in his study comparing Turkish questions in student selection exams with Turkish Language and Literature curriculums in secondary education, revealed that the most questions were related to the main idea of the paragraph. Therefore, it can be said that the studies in the literature and the current research results are similar.

Since higher education entrance exams are carried out in a certain period of time, the number of words that constitute the paragraph namely the length of the paragraph is very important for the exam participants. As the number of words in the paragraph increases, the time spent by students for questions is expected to increase. It was found that the average number of words per paragraph in paragraph questions of Turkish tests for 2018 and after has increased compared to previous years. Therefore, it can be said that it is not enough for the exam participants to understand only what they read, they should have the ability to understand what they read quickly. 